\title{
ANALISIS BIAYA DAN PENDAPATAN USAHA PEDAGANG SAYURAN DI PASAR TAMIN KOTA BANDAR LAMPUNG
}

\author{
(Cost Analysis and Business Revenue of Vegetable Traders in Tamin Market Bandar Lampung City)
}

Romidah Astuti, Wan Abbas Zakaria, Teguh Endaryanto

Jurusan Agribisnis, Fakultas Pertanian, Universitas Lampung, Jl. Prof. Dr. Soemantri Brojonegoro No.1 Bandar Lampung 35141, Telp. 085267944733, e-mail : romidahastuti@ gmail.com

\begin{abstract}
This study aims to analyze the cost structure and the income level of vegetable traders in Tamin Market Bandar Lampung City. This research is conducted in purposively chosen Tamin Market with the consideration that Tamin Market is a center of vegetable trade and the main market in Bandar Lampung City. The data were collected in March 2017 and respondents were 15 vegetable traders who are willing to be interviewed, consisting of five stall traders, five los traders, and five street traders. Data are analyzed descriptively using qualitative and quantitative of cost and income analysis. The result showed that the traders' business cost structure consists of fixed cost and variable cost. The propotion of variable cost is higher than the fixed cost, which is 99 percent of total cost. Variable costs include plastic cost, vegetable purchase, transport, labor, and information. And fixed costs include rent cost, electricity and market facility fees. The average income of stall traders is higher than the loser traders and the street traders. The average income of stall traders is Rp817,055.00 per day, los traders is Rp737,604.00 per day, and street traders is Rp183,455.00 per day.
\end{abstract}

Key words: cost structure, the level of income, vegetable traders

\section{PENDAHULUAN}

Pertumbuhan penduduk yang signifikan akan diikuti dengan kebutuhan konsumsi bagi penduduk itu sendiri. Indonesia merupakan salah satu negara dengan pertumbuhan penduduk yang terus meningkat setiap tahunnya. Penduduk Indonesia telah mencapai 255.461.700 jiwa dengan laju pertumbuhan penduduk 1,49 \% per tahun (Badan Pusat Statistik 2016). Perkembangan penduduk Indonesia yang terus mengalami peningkatan berpengaruh pada meningkatnya kebutuhan bahan pangan bagi masyarakat. Selain bahan pangan pokok, sayuran merupakan bahan pangan yang harus dapat dipenuhi. Pemenuhan permintaan yang ada harus diikuti dengan ketersediaan sayuran melalui kegiatan budidaya yang dilaksanakan oleh petani.

Kebutuhan sayuran bagi masyarakat erat kaitannya dengan kebutuhan akan gizi bagi kesehatan masyarakat itu sendiri. Sayuran merupakan sumber utama dalam pemenuhan gizi. Setiap sayuran akan memberikan manfaat gizi yang berbeda-beda, sehingga pemenuhan sayuran secara seimbang sangat diperlukan. Banyaknya kasus kekurangan gizi menjadi isu penting dalam pemenuhan sayuran di Indonesia, seperti pemenuhan vitamin A, B, C dan lainnya.
Menurut Direktorat Jenderal Hortikultura (2016) di Provinsi Lampung terdapat beberapa sayuran yang memiliki jumlah produksi di atas 100.000 ton pada tahun 2015. Sayuran tersebut adalah terung, tomat, kacang panjang, ketimun, kubis, dan kangkung. Produksi sayuran mengalami peningkatan produksi yang sangat signifikan pada tahun 2015, namun terdapat sayuran yang mengalami penurunan produksi seperti kembang kol, cabe besar, dan cabe rawit.

Konsumsi sayuran menjadi salah satu faktor penting yang dapat mempengaruhi peningkatan produksi sayuran di Provinsi Lampung. Apabila tingkat konsumsi sayuran tinggi maka petani akan berlomba-lomba memproduksi sayuran karena dapat saja memberikan keuntungan yang besar dengan besarnya tingkat permintaan. Faktanya tingkat konsumsi sayuran di Provinsi Lampung terus mengalami penurunan, menurut Badan Ketahanan Pangan Provinsi Lampung (2016) bahwa konsumsi sayuran di Provinsi Lampung pada tahun 2010 dan 2011 cukup tinggi yaitu 76,9 $\mathrm{kg} / \mathrm{kap} / \mathrm{tahun}$ dan $77,8 \mathrm{~kg} / \mathrm{kap} / \mathrm{tahun}$, namun pada tahun selanjutnya terus mengalami penurunan hingga pada tahun 2015 tingkat konsumsi sayuran mencapai 53,2 kg/kap/tahun. Tingkat konsumsi yang masih rendah dapat saja disebabkan oleh beberapa hal yaitu kesadaran akan pentingnya 
mengonsumsi sayuran dan keadaan ekonomi yang menyebabkan suatu rumah tangga hanya mengonsumsi sayuran dalam jumlah yang sedikit, hal tersebut karena harga sayuran yang cukup tinggi serta berfluktiatif. Berdasarkan data harga sayuran di tingkat produsen dan konsumen menurut Direktorat Jenderal Hortikultura (2017), sebagian besar sayuran memiliki marjin yang cukup tinggi, hingga berkali-kali lipat dari harga yang diterima oleh petani sebagai produsen sayuran. Masalah terkait harga sayuran lainnya adalah perubahan harga yang cukup fluktuatif di tingkat konsumen. Harga yang fluktuatif tersebut mengakibatkan produsen dan konsumen kesulitan dalam memperoleh informasi harga secara tepat karena perubahan harga yang tiba-tiba saja terjadi di pasar.

Pasar tradisional merupakan tempat terjadinya transaksi antara pedagang besar dengan pedagang pengecer dan pedagang pengecer dengan konsumen akhir pelaku rumah tangga dan industri. Salah satu pasar tradisional yang ada di Kota Bandar Lampung adalah Pasar Tamin yang merupakan pasar induk. Pedagang sayuran yang ada di Pasar Tamin merupakan pelaku yang terlibat dalam besarnya marjin yang ada antara harga di tingkat konsumen dan produsen. Pedagang sayuran pun merasakan akibat dari fluktuasi harga yang ada di pasar yang berpengaruh pada kinerja biaya dan kinerja pendapatan yang diterima oleh pedagang sayuran. Oleh sebab itu, penelitian ini bertujuan untuk menganalisis struktur biaya dan tingkat pendapatan usaha pedagang sayuran di Pasar Tamin Kota Bandar Lampung.

\section{METODE PENELITIAN}

Penelitian ini dilaksanakan dengan metode survei pada usaha pedagang sayuran di Pasar Tamin dengan pertimbangan bahwa Pasar Tamin merupakan salah satu sentra perdagangan sayuran dan pasar induk di Kota Bandar Lampung. Menurut Ridwan (2008), purposive sampling yaitu teknik sampling yang digunakan peneliti jika peneliti mempunyai pertimbangan-pertimbangan tertentu di dalam pengambilan sampelnya atau penetuan sampel untuk tujuan tertentu. Pengumpulan data penelitian dilakukan pada bulan Maret 2017. Data yang dikumpulkan terdiri dari data primer yang diperoleh dari 15 responden yaitu pedagang sayuran eceran yang ada di pasar Tamin yang terdiri dari pedagang kios, los amparan, dan amparan kaki lima dengan teknik wawancara menggunakan kuisioner.
Analisis data yang digunakan untuk menghitung struktur biaya pada pedagang sayur menggunakan perhitungan biaya total. Menurut Soekartawi (2003), biaya dibedakan menjadi dua yaitu biaya tetap dan biaya tidak tetap.

\section{a. Biaya Tetap (fixed cost)}

Biaya tetap adalah biaya yang besar kecilnya tidak mempengaruhi jumlah produk yang dijual yang meliputi sewa tempat dagang, iuran, listrik, dan penyusutan yang dinyatakan dalam rupiah. Cara menghitung biaya tetap (fixed cost) adalah sebagai berikut:

$$
\mathrm{TFC}=\sum_{i=1}^{n} \mathrm{X}_{\mathrm{PX}}
$$

Keterangan:

TFC : Biaya tetap (fixed cost)

$\mathrm{X}$ : Jumlah fisik yang membentuk biaya tetap

Px : Hasil input

n : Macam input

\section{b. Biaya Variabel (variable cost)}

Biaya variabel adalah biaya yang besar kecilnya mempunyai pengaruh langsung terhadap jumlah produk yang dijual. Biaya variabel meliputi biaya pembelian sayuran, plastik, angkut, tenaga kerja, dan pencarian informasi. Biaya variabel (variable $\operatorname{cost}$ ) dapat dihitung menggunakan rumus:

$\mathrm{TVC}=\sum_{i=1}^{n} \mathrm{BV}$

Keterangan:

TVC : Biaya tetap (variable cost)

$\mathrm{Bv}$ : Biaya variabel dari setiap input

$\mathrm{n}$ : Banyak input

c. Biaya Total (total cost)

Menurut Rahim dan Hastuti (2007), total biaya atau total cost adalah jumlah dari biaya tetap atau fixed cost dan biaya tidak tetap atau variable cost. Untuk menghitung total biaya (total cost) dapat digunakan rumus:

$\mathrm{TC}=\mathrm{TFC}+\mathrm{TVC}$

Keterangan:

TC : Biaya total

TFC : Biaya tetap total 
TVC : Biaya variabel total

Selain biaya tetap dan variabel, dalam penelitian ini biaya juga digolongkan ke dalam biaya tunai dan biaya diperhitungkan berdasarka penggunaannya. Biaya tunai merupakan biaya yang dikeluarkan secara langsung oleh pedagang sayuran yang terdiri dari biaya tetap dan biaya variabel seperti yang telah dijelaskan sebelumnya. Biaya diperhitungkan merupakan biaya yang seharusnya dikeluarkan tetapi tidak dikeluarkan secara langsung oleh pedagang sayuran namun tetap harus diperhitungkan.

Biaya total dapat juga diperoleh dengan menggunakan rumus:

$\mathrm{TC}=$ Biaya Tunai + Biaya Diperhitungkan

Biaya tunai dalam penelitian ini terdiri dari biaya pembelian sayur, plastik, angkut, tenaga kerja, pencarian informasi, sewa tempat, listrik, dan iuran fasilitas pasar. Biaya diperhitungkan terdiri dari biaya tenaga kerja dalam keluarga dan penyusutan. Biaya lain yang dikeluarkan oleh pedagang dalam kegiatannya adalah biaya transaksi. Menurut North dan Thomas (1973) dalam Anggraini (2005), biaya transaksi (transaction cost) (TrC) meliputi :

1) Biaya pencarian (search cost) $\left(Z_{1}\right)$ yaitu biaya untuk mendapatkan informasi tentang keuntungan atau kerugian suatu transaksi (cost of allocating information about opportunity of the exchange).

2) Biaya negosiasi (negotiation cost) $\left(\mathrm{Z}_{2}\right)$ yaitu biaya merundingkan syarat -syarat suatu transaksi (cost of negotiating the terms of the exchange).

3) Biaya pelaksanaan (enforcement cost) $\left(\mathrm{Z}_{3}\right)$ yaitu biaya untuk melaksanakan suatu kontrak (cost of enforcing the contract).

Biaya transaksi yang terdapat dalam penelitian ini hanya biaya pencarian, hal tersebut dikarenakan pedagang sayuran yang ada di Pasar Tamin adalah pedagang sudah memiliki pemasok tetap sehingga pedagang cukup membutuhkan informasi terkait harga dan ketersediaan sayuran saja.

Pendapatan usaha adalah keuntungan yang diperoleh setelah penerimaan (dari hasil penjualan) produk sayuran dikurangkan dengan biaya yang dikeluarkan dalam proses kegiatan pemasaran. Informasi yang dibutuhkan dalam analisis pendapatan usaha adalah total penerimaan dan total pengeluaran usaha dalam jangka waktu yang telah ditetapkan. Total penerimaan diperoleh dari total produk sayuran yang dijual lalu dikalikan dengan harga jual masing-masing produk sayuran. Total pengeluaran adalah semua biaya yang dikeluarkan dalam kegiatan usaha penjualan sayuran. Total pendapatan adalah total penerimaan dikurangi dengan total biaya dalam suatu kegiatan usaha.

Menurut Mubyarto (1994), total penerimaan dari suatu usaha dapat dihitung dengan rumus:

$\mathrm{TR}=\mathrm{Pi} \times \mathrm{Qi}$

Keterangan:

TR : Total penerimaan ( $\mathrm{Rp} / \mathrm{hari})$

$\mathrm{P}$ : Harga sayuran ke-i $(\mathrm{Rp} / \mathrm{Kg})$

Q : Jumlah sayuran terjual ke-i (Kg/hari)

Besarnya pendapatan/laba diperoleh dari:

$\pi=\mathrm{TR}-\mathrm{TC}$

Keterangan:

$\pi \quad: \quad$ Pendapatan $(\mathrm{Rp} / \mathrm{hari})$

TR : Total penerimaan (Rp/hari)

TC : Total biaya (Rp/hari)

Kriteria:

1. Jika total penerimaan $>$ total biaya, maka usaha untung.

2. Jika total penerimaan = total biaya, maka usaha berada pada titik impas.

3. Jika total penerimaan < total biaya, maka usaha tersebut merugi.

Total biaya atau Total Cost (TC) merupakan keseluruhan biaya yang dikeluarkan oleh pedagang sayur baik itu biaya tetap maupun biaya variabel dan biaya tunai maupun biaya di perhitungkan. Metode ini juga digunakan pada penelitian Heriani, Zakaria, dan Soelaiman (2013) dan Setiani, Zakaria, dan Adawiyah (2015) dalam menghitung besarnya keuntungan dalam usahatani.

\section{HASIL DAN PEMBAHASAN}

\section{Karakteristik Pedagang}

Pada penelitian ini terdapat tiga jenis pedagang sayuran di Pasar Tamin yaitu pedagang kios, los amparan dan amparan kaki lima. Sebagian besar pedagang memiliki umur sedang yaitu diantara 4052 tahun sebanyak 60 persen. Tingkat pendiikan pedagang paling tinggi adalah SMA dan paling rendah adalah SD, sebagian besar pedagang berpendidikan SMA atau sederajat dengan persentase 60 persen. Lama berdagang responden pada kisaran 21-30 tahun sebanyak 40 persen. 
Jumlah tanggungan keluarga pedagang sebagian besar adalah 4-6 orang dengan persentase 53,33 persen. Jumlah jenis sayuran yang dijual sebagian besar pedagang di Pasar Tamin adalah 9-12 jenis sayuran dengan persentase sebesar 53,33 persen. Sebagian besar pedagang sayuran mengeluarkan modal yang berkisar antara Rp50.000,00 Rp1.000.000,00 dengan rata-rata modal sebesar Rp938.333,00. Jenis sayuran yang diteliti adalah semua jenis sayuran yang dijual oleh pedagang yang merupakan responden di Pasar Tamin.

\section{Pola Penjualan Sayuran}

Pola penjualan yang terjadi di Pasar Tamin khususnya pada pedagang sayuran dibedakan menjadi tiga, yaitu tingkat penjualan tinggi, normal, dan rendah. Tingkat penjualan tinggi menunjukkan bahwa jumlah sayuran yang dijual cukup banyak atau di atas rata-rata. Tingkat Penjualan normal menunjukkan bahwa jumlah sayuran yang dapat dijual oleh pedagang cukup normal atau biasa saja. Tingkat penjualan rendah menunjukkan bahwa jumlah sayuran yang dapat dijual oleh pedagang cukup sedikit. Jumlah sayuran yang diteliti adalah 34 komoditas dengan tingkat penjualan perhari seperti pada Tabel 1 . Komoditas sayuran dengan penjualan yang lebih tinggi dibandingkan sayuran lainnya adalah cabai, bawang, buncis, kol, wortel, kentang, dan tomat. Sayuran daun lainnya terdiri dari seledri, daun bawang, sawi putih, sawi pahit, kemangi, bayam, kangkung, daun singkong, dan tunas kol. Sayuran buah lainnya terdiri dari timun, labu siam, paprika, terung, soleng, kacang panjang, lencak, dan pare. Penggolongan sayuran tersebut berdasarkan teori menurut Kurnia, Suganda, Erfandi, dan Kusnadi (2004).

Tingkat penjualan sayuran di pasar Tamin dalam satu tahun terakhir mengalami perubahan setiap bulannya. Tingkat penjualan tinggi yang dirasakan oleh pedagang pada bulan Juli, Agustus, September, Desember, dan januari. Hal tersebut dikarenakan pada bulan-bulan tersebut terdapat perayaan hari besar seperti bulan puasa dan hari raya, menurut pedagang pada bulan-bulan tersebut penjualan cukup tinggi. Tingkat penjualan normal pada bulan April, Mei, Juni, Februari, dan Maret. Tingkat penjualan rendah dirasakan pedagang pada bulan Oktober dan November, berdasarkan kegiatan perdagangannya.

Kegiatan perdagangan yang dilakukan oleh pedagang tentu tidak selalu mudah, tentu terdapat kendala yang dialami oleh pedagang dalam pedagangannya. Kendala tersebut diantaranya adalah barang dagangan yang tidak selalu habis setiap hari, hal tersebut menjadi masalah tersendiri bagi pedagang untuk menggunakan berbagai cara agar tetap memperoleh keuntungan dari kegiatan perdagangan yang dilakukan, pedagang sayuran harus mencari cara agar sayuran dapat dijual kembali keesokan harinya tanpa mengalami kerugian. Beberapa cara yang dilakukan oleh pedagang sayuran yang ada di Pasar Tamin adalah dengan mencampur kembali sayuran kemarin dengan yang baru, membersihkan sayuran dari bagian yang busuk (seperti kol yang dibersihkan bagian luarnya), menjual kembali dengan harga dibawah rata-rata, dan menjual sayuran dengan pelaku usaha lain yang mengolah sayuran (seperti penggilingan cabai, bawang merah, bawang putih, dan lain-lain).

Marjin harga penjualan merupakan salah satu Berdasarkan hasil penelitian yang telah dilakukan dapat diketahui bahwa marjin harga yang digunakan oleh pedagang sayuran relatif berbeda pada setiap komoditas sayuran. Marjin yang digunakan setiap pedagang juga berbeda tergantung pada metode penentuan marjin yang digunakan oleh pedagang. Rata-rata marjin harga yang digunakan oleh pedagang dari seluruh komoditas adalah Rp3.606,00 pada setiap kilogram sayuran yang dijual oleh pedagang.

Margin harga paling tinggi yaitu pada komoditas paprika dan kemangi yaitu sebesar Rp15.000,00 dan Rp10.667,00 per kilogram.Hal tersebut dapat disimpulkan bahwa marjin harga yang digunakan oleh pedagang sayuran di Pasar Tamin cukup tinggi, sehingga harga jual yang diterima oleh konsumen menjadi tinggi pula. Tingginya harga yang diterima oleh konsumen tentu memberikan dampak kepada konsumen untuk menguragi jumlah pembelian sayuran atau bahkan tidak membeli sama sekali.

\section{Biaya Usaha Dagang Sayuran}

Biaya usaha dagang dalam penelitian ini terdiri dari biaya tetap dan biaya variabel, biaya tunai dan biaya diperhitungkan, dan biaya transaksi. Biayabiaya tersebut dikeluarkan secara periodik, terdapat biaya yang di keluarkan perhari, perbulan dan pertahun, seperti halnya biaya pembelian sayuran yang dikeluarkan setiap hari, biaya listrik yang dikeluarkan per bulan, dan biaya sewa tempat yang dikeluarkan per tahun. 
Tabel 1. Rata-rata tingkat penjualan sayuran berdasarkan jenis sayuran $(\mathrm{kg} / \mathrm{hari})$

\begin{tabular}{|c|c|c|c|c|c|c|c|c|c|c|}
\hline \multirow[t]{2}{*}{ No. } & \multirow[t]{2}{*}{ Jenis sayuran } & \multicolumn{3}{|c|}{ Jumlah penjualan kios } & \multicolumn{3}{|c|}{ Jumlah penjualan los amparan } & \multicolumn{3}{|c|}{$\begin{array}{l}\text { Jumlah penjualan amparan kaki } \\
\text { lima }\end{array}$} \\
\hline & & Tinggi & Normal & Rendah & Tinggi & Normal & Rendah & Tinggi & Normal & Rendah \\
\hline 1. & $\begin{array}{l}\text { Cabai merah } \\
\text { besar }\end{array}$ & 107,14 & 46,79 & 23,21 & 40,54 & 17,75 & 8,46 & 23,05 & 11,76 & 7,48 \\
\hline 2. & $\begin{array}{l}\text { Cabai hijau } \\
\text { besar }\end{array}$ & 92,86 & 47,14 & 22,14 & - & - & - & 2,00 & 1,00 & 0,50 \\
\hline 3. & Cabai rawit & 65,00 & 30,00 & 16,07 & 30,64 & 14,43 & 5,82 & 16,38 & 7,95 & 4,45 \\
\hline 4. & Bawang putih & 68,50 & 41,79 & 20,75 & 48,57 & 17,48 & 9,86 & 42,14 & 26,43 & 6,43 \\
\hline 5. & Bawang merah & 87,38 & 42,14 & 31,67 & 45,95 & 21,19 & 9,62 & 38,57 & 22,86 & 5,00 \\
\hline 6. & Buncis & 70,24 & 38,81 & 23,57 & 43,04 & 22,82 & 10,36 & 12,86 & 6,86 & 5,57 \\
\hline 7. & Kol & 60,95 & 39,29 & 29,68 & 43,04 & 28,39 & 9,43 & 39,29 & 24,29 & 12,14 \\
\hline 8. & Wortel & 71,67 & 32,14 & 18,33 & 40,79 & 23,57 & 12,00 & 12,50 & 6,50 & 4,21 \\
\hline 9. & Tomat & 61,67 & 38,10 & 17,14 & 51,79 & 26,43 & 11,18 & 26,18 & 15,14 & 8,54 \\
\hline 10. & Kentang & 84,46 & 61,79 & 33,39 & 49,76 & 30,00 & 14,10 & 26,67 & 16,62 & 7,33 \\
\hline 11. & $\begin{array}{l}\text { Sayuran daun } \\
\text { lainnya }\end{array}$ & 217,50 & 107,86 & 64,85 & 97,86 & 59,29 & 34,72 & 153,50 & 93,72 & 50,93 \\
\hline 12. & $\begin{array}{l}\text { Sayuran buah } \\
\text { lainnya }\end{array}$ & 180,00 & 127,85 & 54,45 & 234,28 & 133,10 & 71,97 & 125,41 & 75,70 & 42,77 \\
\hline
\end{tabular}

Biaya tetap terdiri dari biaya sewa tempat, iuran fasilitas, dan listrik. Biaya tetap yang dikeluarkan oleh setiap pedagang bervariasi, hal tersebut ditentukan oleh jenis pedagang, yaitu pedagang kios, los amparan dan amparan kaki lima.

Pedagang amparan kaki lima tidak mengeluarkan biaya sewa tempat, hal tersebut dikarenakan pedagang amparan kaki lima tidak memiliki tempat berjualan. Biaya sewa tempat dagang pada pedagang kios di Pasar Tamin berkisar antara Rp3.500.000,00 sampai dengan Rp5.000.000,00 per tahun dan biaya sewa tempat dagang pada pedagang los amparan di Pasar Tamin berkisar antara Rp2.544.000,00 sampai dengan Rp3.200.000,00 per tahun. Perbedaan sewa tempat dagang yang ada di Pasar Tamin didasarkan pada lokasi tempat dagang, di dalam pasar atau di pinggiran pasar (bagian luar). Menurut informasi yang diberikan pedagang, sewa temapt dagang yang ada di bagian luar atau depan memiliki biaya sewa yang lebih tinggi dibandingkan dengan di dalam pasar.

Biaya iuran fasilitas di Pasar Tamin terdiri dari iuran tempat, keamanan, dan kebersihan. Biaya tersebut dibayarkan kepada petugas pasar yang diatur oleh Dinas Pengelolaan Pasar Kota Bandar Lampug yang sekarang berada dibawah naungan Dinas Perdagangan Kota Bandar Lampung. Biaya yang dikeluarkan oleh pedagang kios, los amparan dan amparan kaki lima berbeda-beda. Biaya iuran fasilitas tersebut dibayarkan secara rutin setiap hari oleh para pedagang sayuran. Iuran yang dibayarkan oleh pedagang kios sebesar Rp6.000,00 per hari, Pedagang los amparan mengeluarkan iuran Rp5.000,00 per hari, pedagang amparan kaki lima membayar iuran paling kecil dibanding dua jenis pedagang lainnya, yaitu hanya sebesar Rp2.000,00 per hari. Pedagang amparan kaki lima tidak membayar iuran tempat. Biaya tetap lainnya yang dikeluarkan oleh pedagang sayuran di Pasar Tamin adalah biaya listrik. Listrik yang digunakan oleh pedagang sayuran untuk penerangan di lokasi penjualan. Biaya listrik yang dikeluarkan oleh pedagang kios adalah sebesar Rp30.000,00 per bulan, pedagang los amparan membayar sebesar Rp20.000,00 per bulan, sedangkan pedagang amparan kaki lima tidak mengeluarkan biaya listrik. Besarnya biaya listrik tersebut berdasarkan pada penggunan lampu oleh pedagang, jika pedagang ingin menambahkan lampu maka biaya listrik ditambah sesuai dengan jumlah lampu yang digunakan oleh pedagang.

Biaya variabel terdiri dari biaya pembelian plastik, pembelian sayuran, pengangkutan, upah tenaga kerja dan biaya pencarian informasi. Biaya variabel yang dikeluarkan pada setiap tingkat penjualan berbeda-beda. Biaya paling besar yang dikeluarkan adalah biaya pembelian sayuran yang merupakan biaya pokok dalam melakukan usaha dagang sayuran. Jumlah pengeluaran biaya pembelian sayuran pun berdasarkan tingkat penjualan yang ada pada tingkat penjualan tinggi maka pedagang akan membeli sayuran dalam jumlah yang lumayan banyak untuk memenuhi permintaan konsumen.

Biaya plastik adalah biaya pembelian plastik yang digunakan dalam pengemasan sayuran. Jumlah Plastik yang digunakan oleh pedagang kios dalam sehari pada tingkat penjualan tinggi bisa mencapai delapan pack, sedangkan paling sedikit pedagang 
hanya menggunakan satu pack plastik. Harga per pack plastik yang digunakan pedagang berbedabeda berdasarkan kualitas, ukuran dan tempat pembelian plastik. Kisaran harga plastik yang digunakan pedagang antara Rp11.000,00 Rp15.000,00 per pack. Rata-rata biaya angkut yang dikeluarkan bervariasi bedasarkan jumlah sayuran yang perlu diangkut, kisaran biaya angkut yang dikeluarkan oleh pedagang antara Rp12.000,00 - Rp70.000,00 per hari.

Kisaran jumlah tenaga kerja yang dimiliki oleh pedagang sayuran di Pasar Tamin adalah antara satu hingga 10 orang tenaga kerja, dengan kisaran upah dari Rp30.000,00 - Rp50.000,00 per hari, dengan rata-rata upah sebesar $\mathrm{Rp} 46.000,00$ per hari. Tingkat upah yang diberikan berasarkan tingkat penjualan yang dilakukan dan tidak ada aturan mengenai upah tenaga kerja, upah tersebut berdasarkan negosiasi antara pedagang dan tenaga kerja yang dipekerjakan. Biaya tenaga kerja dalam keluarga yang diinginkan oleh pedagang pada penjualan tinggi dan normal biaya tenaga kerja yang diinginkan adalah Rp50.000,00 per hari dan pada tingkat penjualan rendah sebesar Rp40.000,00 per hari. Biaya penyusutan yang dikeluarkan oleh pedagang berdasarkan pada jumlah peralatan yang dimiliki, semakin banyak peralatan yang dimiliki maka semakin besar biaya penyusutan yang dikeluarkan. Rata-rata biaya penyusutan peralatan yang dikeluarkan oleh pedagang kios adalah Rp336,99 per hari, pedagang los amparan sebesar Rp381,26 per hari dan pedagang amparan kaki lima sebesar Rp176,43 per hari.

Menurut North dan Thomas (1973) dalam Anggraini (2005), biaya transaksi terdiri dari biaya pencarian dan informasi, biaya negosiasi dan keputusan, serta biaya pengawasan dan pelaksanaan. Berdasarkan hasil penelitian, pelaksanaan transaksi antara pedagang sayuran dengan pemasok berjalan tanpa diatur dengan kontrak secara tertulis, karena tidak ada perjanjian yang ditandatangani bersama oleh kedua belah pihak di atas kertas. Transaksi yang dilakukan oleh pedagang sayuran dan pemasok dijalankan berdasarkan kontrak lisan. Pedagang sayuran di Pasar tamin secara tidak langsung melakukan kesepakatan secara lisan dengan pemasok bahwa akan selalu membeli barang dagangan dalam hal ini sayuran kepada pemasok tersebut. Unsur biaya transaksi terdiri dari biaya pencarian informasi, biaya pemilihan dan pemeriksaan sayuran, biaya negosiasi, dan biaya pencarian pemasok langganan. Hasil tersebut selaras dengan penelitian yang dilakukan oleh Pambudi (2014) mengenai biaya transaksi dan modal sosial antara pedagang dan pemasok sayuran.

Biaya transaksi adalah biaya yang dikeluarkan oleh pedagang selama melakukan transaksi. Biaya informasi meliputi biaya penggunaan pulsa, biaya transportasi ketika pedagang memerlukan bertemu langsung dengan pemasok dalam mencari informasi yang dibutuhkan. Biaya transaksi yang dikeluarkan oleh pedagang sayuran di Pasar Tamin sangat bervariasi mulai dari Rp0,00 sampai dengan Rp15.000,00 per hari. Pedagang yang tidak mengeluarkan biaya pencarian informasi merupakan pedagang yang pemasoknya berada di Pasar Tamin pula, sehingga tidak membutuhkan biaya dalam melakukan kegiatan pencarian informasi dengan pemasoknya.

\section{Penerimaan, Pendapatan, dan keuntungan}

Penerimaan adalah total penjualan yang dapat dihasilkan oleh pedagang, belum di kurangi dengan biaya-biaya yang dikeluarkan. Keberhasilan suatu usaha dapat dinilai dari berbagai faktor, salah satunya adalah dengan melihat berapa besar keuntungan yang diperoleh. Pendapatan merupakan selisih antara penerimaan dengan biaya tunai yang dikeluarkan oleh pedagang secara langsung, pendapatan dalam hal ini dapat juga disebut dengan keuntungan atas biaya tunai. Keuntungan merupakan selisih antara penerimaan dan pengeluaran total yang meliputi biaya tunai dan biaya diperhitungkan, baik pengeluaran tunai dan total. Selisih yang bernilai positif menunjukkan bahwa usaha tersebut mendapat keuntungan.

Pedagang kios adalah pedagang yang berdagang di kios dengan luas tempat dagang 4 x 4 meter, jumlah sayuran yang dijual dengan modal yang lebih besar dibandingkan pedagang los amparan dan pedagang amparan kaki lima. Penerimaan yang didapat oleh pedagang kios pada tingkat penjualan tinggi adalah Rp12.654.571,00 perhari, pada tingkat penjualan normal sebesar Rp5.612.786,00 per hari dan pada tingkat penjualan rendah sebesar Rp3.704.286,00 per hari. Rincian rata-rata tingkat keuntungan pada usaha pedagang sayuran di Pasar Tamin dapat dilihat pada Tabel 2. Besarnya tingkat penerimaan yang dihasilkan oleh pedagang kios bergantung pada seberapa tingkat penjualan yang mampu dilakukan oleh pedagang sayuran tersebut. Tingkat penerimaan yang di peroleh pedagang merupakan 
hasil dari jumlah penjualan dikali dengan harga jual.

Rata-rata keuntungan atas biaya tunai yang diterima oleh pedagang kios pada tingkat penjualan tinggi adalah Rp1.656.081,00 per hari, pada tingkat penjualan normal adalah Rp790.262,00 per hari, sedangkan pada tingkat penjualan rendah adalah Rp229.833,00 per hari. Kisaran keuntungan terhadap biaya tunai yang diterima oleh pedagang kios dalam penelitian ini pada tingkat penjualan rendah justru mengalami kerugian sebesar Rp12.434,00 per hari dan rata-rata keuntungan terbesar adalah Rp601.124,00 per hari.

Pedagang los amparan adalah pedagang yang berdagang di tempat seperti kios namun yang tidak memiliki dinding dan berukuran lebih kecil. Jumlah sayuran yang dijual dan modal yang digunakan lebih sedikit dibandingkan pedagang kios. penerimaan yang didapat oleh pedagang los amparan pada tingkat penjualan tinggi adalah
Rp8.334.714,00 per hari, pada tingkat penjualan normal sebesar Rp3.626.029,00 per hari dan pada tingkat penjualan rendah sebesar Rp1.788.929,00 per hari. Tingkat penerimaan yang di peroleh pedagang merupakan hasil dari jumlah penjualan dikali dengan harga jual. Harga yang diberikan oleh pedagang los amparan pun berbeda-beda berdasarkan penentuan harga jual masing-masing pedagang. Rata-rata keuntungan atas biaya tunai yang diterima oleh pedagang los amparan pada tingkat penjualan tinggi adalah Rp1.528.819,00 per hari, pada tingkat penjualan normal adalah Rp728.333,00 per hari, sedangkan pada tingkat penjualan rendah adalah Rp125.805,00 per hari. Kisaran keuntungan terhadap biaya tunai yang diterima oleh pedagang los amparan dalam penelitian ini pada tingkat penjualan rendah justru mengalami kerugian sebesar Rp103.386,00 per hari dan rata-rata keuntungan terbesar adalah Rp275.614,00 per hari.

Tabel 2. Rincian biaya dan keuntungan pada tiga jenis pedagang sayuran di Pasar Tamin (Rp/hari)

\begin{tabular}{|c|c|c|c|c|c|c|c|c|c|c|}
\hline \multirow{2}{*}{ No } & \multirow{2}{*}{ Keterangan } & \multicolumn{3}{|c|}{ Tingkat penjualan (kios) } & \multicolumn{3}{|c|}{$\begin{array}{l}\text { Tingkat penjualan (los } \\
\text { amparan) }\end{array}$} & \multicolumn{3}{|c|}{$\begin{array}{c}\text { Tingkat penjualan (amparan } \\
\text { kaki lima) }\end{array}$} \\
\hline & & Tinggi & Normal & Rendah & Tinggi & Normal & Rendah & Tinggi & Normal & Rendah \\
\hline 1 & Penerimaan & 12.654 .571 & 5.612 .786 & 3.704 .286 & 8.334 .714 & 3.626 .029 & 1.788 .929 & 3.376 .571 & 1.6539 .257 & 936.800 \\
\hline \multirow[t]{19}{*}{2} & Biaya produksi & & & & & & & & & \\
\hline & Biaya Tunai & & & & & & & & & \\
\hline & Biaya Variabel & 10.979 .381 & 4.803 .414 & 3.455 .343 & 6.793 .314 & 2.884 .114 & 1.649 .543 & 2.900 .753 & 1.346 .481 & 852.500 \\
\hline & Biaya plastik & 59.000 & 32.200 & 14.600 & 50.600 & 31.800 & 15.800 & 35.600 & 16.100 & 11.500 \\
\hline & $\begin{array}{l}\text { Biaya pembelian } \\
\text { sayur }\end{array}$ & 10.675 .714 & 4.548 .214 & 3.242 .743 & 6.650 .714 & 2.765 .314 & 1.558 .143 & 2.833 .486 & 1.303 .714 & 816.000 \\
\hline & Biaya angkut & 116.667 & 100.000 & 100.000 & 32.000 & 31.000 & 29.600 & 21.667 & 21.667 & 20.000 \\
\hline & Biaya tenaga kerja & 115.000 & 115.000 & 90.000 & 50.000 & 50.000 & 40.000 & - & - & - \\
\hline & $\begin{array}{l}\text { Biaya pencarian } \\
\text { informasi }\end{array}$ & 13.000 & 8.000 & 8.000 & 10.000 & 6.000 & 6.000 & 10.000 & 5.000 & 5.000 \\
\hline & Biaya tetap & 19.110 & 19.110 & 19.110 & 13.581 & 13.581 & 13.581 & 2.000 & 2.000 & 2.000 \\
\hline & Biaya sewa & 12.110 & 12.110 & 12.110 & 7.914 & 7.914 & 7.914 & - & - & - \\
\hline & Biaya listrik & 1.000 & 1.000 & 1.000 & 667 & 667 & 667 & - & - & - \\
\hline & $\begin{array}{l}\text { Biaya iuran } \\
\text { fasilitas }\end{array}$ & 6.000 & 6.000 & 6.000 & 5.000 & 5.000 & 5.000 & 2.000 & 2.000 & 2.000 \\
\hline & Total biaya tunai & 10.998 .491 & 4.822 .524 & 3.474 .453 & 6.806 .895 & 2.897 .695 & 1.663 .124 & 2.902 .752 & 1.348 .481 & 854.500 \\
\hline & $\begin{array}{l}\text { Biaya diperhitungkan } \\
\text { Biaya variabel }\end{array}$ & 80.000 & 80.000 & 64.000 & 60.000 & 60.000 & 48.000 & 70.000 & 70.000 & 56.000 \\
\hline & $\begin{array}{l}\text { Biaya tenaga kerja } \\
\text { dalam keluarga }\end{array}$ & 80.000 & 80.000 & 64.000 & 60.000 & 60.000 & 48.000 & 70.000 & 70.000 & 56.000 \\
\hline & Biaya tetap & 337 & 337 & 337 & 381 & 381 & 381 & 176 & 176 & 176 \\
\hline & Biaya Penyusutan & 337 & 337 & 337 & 381 & 381 & 381 & 176 & 176 & 176 \\
\hline & $\begin{array}{l}\text { Total biaya } \\
\text { diperhitungkan }\end{array}$ & 80.337 & 80.337 & 60.337 & 60.381 & 60.381 & 48.381 & 70.176 & 70.176 & 56.176 \\
\hline & Total biaya & 11.078 .828 & 4.902 .861 & 3.538 .790 & 6.867 .277 & 2.958 .077 & 1.711 .505 & 2.972 .929 & 1.418 .657 & 910.676 \\
\hline \multirow[t]{3}{*}{3} & Keuntungan & & & & & & & & & \\
\hline & $\begin{array}{l}\text { Keuntungan atas biaya } \\
\text { tunai }\end{array}$ & 1.656 .081 & 790.262 & 229.833 & 1.527 .819 & 728.333 & 125.805 & 473.819 & 190.776 & 82.300 \\
\hline & $\begin{array}{l}\text { Keuntungan atas biaya } \\
\text { total }\end{array}$ & 1.575 .744 & 709.925 & 165.496 & 1.467 .438 & 667.952 & 77.423 & 403.643 & 120.600 & 26.124 \\
\hline
\end{tabular}


Pedagang amparan kaki lima adalah pedagang yang berdagang amparan kaki lima yang tidak memiliki tempat dagang yang permanen seperti halnya pedagang kios dan los amparan. Penerimaan yang didapat oleh pedagang amparan kaki lima pada tingkat penjualan tinggi adalah Rp3.376.571,00 per hari, pada tingkat penjualan normal sebesar Rp1.539.257,00 per hari dan pada tingkat penjualan rendah sebesar Rp936.800,00 per hari. Tingkat penerimaan yang di peroleh merupakan hasil dari jumlah penjualan dikali dengan harga jual. Harga yang diberikan oleh pedagang amparan kaki lima pun berbeda-beda berdasarkan penentuan harga jual masing-masing pedagang. Rata-rata keuntungan atas biaya tunai yang diterima oleh pedagang amparan kaki lima pada tingkat penjualan tinggi adalah Rp473.819,00 per hari, pada tingkat penjualan normal adalah Rp190.776,00 per hari, sedangkan pada tingkat penjualan rendah adalah Rp82.300,00 per hari. Kisaran keuntungan terhadap biaya tunai yang diterima oleh pedagang amparan kaki lima dalam penelitian ini pada tingkat penjualan rendah justru mengalami kerugian sebesar Rp101.571,00 per hari dan rata-rata keuntungan terbesar adalah Rp251.429,00 per hari. Hasil penelitian menunjukkan bahwa usaha pedagang sayuran memiliki keuntungan yang cukup tinggi. Hal ini selaras dengan penelitian yang dilakukan oleh zuhriski (2008) mengenai pendapatan pedagang sayur keliling di Kelurahan Tegallega Kota Bogor.

\section{KESIMPULAN}

Struktur biaya usaha pedagang terdiri dari biaya tetap dan biaya variabel. Proporsi biaya variabel lebih tinggi dibandingkan dengan biaya tetap yaitu sebesar 99 persen dari biaya total. Biaya variabel terdiri dari biaya plastik, pembelian sayur, angkut, tenaga kerja, dan informasi. Biaya tetap yaitu biaya sewa, listrik, dan iuran fasilitas pasar. Ratarata pendapatan usaha pedagang sayuran kios lebih tinggi dibandingkan dengan pedagang los amparan dan amparan kaki lima. Rata-rata pendapatan pedagang kios sebesar Rp817.055,00 per hari, pedagang los amparan sebesar Rp737.604,00 per hari, dan pedagang amparan kaki lima sebesar Rp183.455,00 per hari.

\section{DAFTAR PUSTAKA}

Anggraini E. 2005. Analisis Biaya Transaksi dan Penerimaan Nelayan dan Petani di Pelabuhan Ratu Kabupaten Sukabumi. Thesis. Sekolah Pascasarjana IPB. Bogor.
Badan Ketahanan Pangan. 2016. Tingkat Konsumsi Pangan di Provinsi Lampung. Badan Ketahanan Pangan Provinsi Lampung. Bandar Lampung.

Badan Pusat Statistik. 2016. Statistik Indonesia tahun 2016. https://www.bps.go.id/ [9 januari 2017].

Direktorat Jenderal Hortikultura. 2016. Produksi Sayuran di Indonesia 2011-2015. Direktorat Jenderal Hortikultura - Kementrian Pertanian. Jakarta.

2017. Data Harga Aneka Sayur di Provinsi Lampung Menurut Bulan Tahun 2016. Direktorat Jenderal Hortikultura - Kementrian Pertanian. Jakarta.

Heriani N, Zakaria WA, Soelaiman A. 2013. Analisis keuntungan dan risiko usahatani tomat di Kecamatan Sumberejo Kabupaten Tanggamus. JIIA, 1 (2) : 169-173. http:// jurnal.fp.unila.a.id/index.php/JIA/article/view /244/243 [8 Desember 2017].

Kurnia U, Suganda D, Erfandi H, dan Kusnadi. 2004. Teknologi Konservasi Tanah pada Budidaya Sayuran Dataran Tinggi dalam Teknologi Konservasi Tanah Lahan Kering Berlereng. Pusat Penelitian dan Pengembangan Tanah dan Agroklimat, Bogor. Bogor.

Mubyarto. 1994. Pengantar Ekonomi Pertanian. Pustaka LP3ES. Jakarta.

Pambudi NT. 2014. Biaya Transaksi dan Modal Sosial antara Pedagang dan Pemasok (Studi pada Pedagang Sayur di Pasar Belimbing Kota Malang). Skripsi. Fakultas Ekonomi dan Bisnis, Universitas Barwijaya. Malang.

Rahim A dan Hastuti. 2007. Ekonomi Pertanian. Penebar Swadaya. Jakarta.

Ridwan. 2008. Metode dan Teknik Menyusun Tesis. CV. Alfabeta. Bandung.

Setiani N, Zakaria WA, dan Adawiyah R. 2015. Analisis keuntungan usahatani antar pola tanam di lahan sawah Desa Tata Karya Kecamatan Abung Surakarta Kab. Lampung Utara. JIIA, 3 (2): 122-129. http://jurnal. fp.unila.a.id/index.php/JIA/article/view/1030/ 129. [8 Desember 2017].

Soekartawi. 2003. Prinsip Ekonomi Pertanian. Rajawali Press. Jakarta.

Zuhriski H. 2008. Analisis Pendapatan Pedagang Sayur Keliling di Kelurhan Tegallega Kota Bogor. Skripsi. Fakultas pertanian IPB. Bogor. 